Jan Obrtlik

\title{
Výzvy k transformaci: Česká sakrální architektura v první polovině dvacátého století
}

Klíčová slova: Architektura sakrální; 20. století; Funkcionalismus.

Kontakt: jobrtlik@yahoo.com

Školitel: Vladimír Šlapeta

Tematický okruh: Architektura

Transformation Challenges: Czech Church Architecture in the First Half of the Twentieth Century

During the first half of the twentieth century, church architecture in the Central European area - determined, around 1900, by the framework of architectural historicism and eclecticism - absorbed a number of influences that led to its radical transformation.

On one level, this transformation followed from the development of architecture as a field, where radical changes took place in the functionalist era between the two world wars. It took long for the revolution to reach the church milieu, with the exception of churches for new denominations who sought to be different from the established ones. Therefore, conservative views and modern trends opposing them existed in parallel. 
Sakrální architektura středoevropského prostoru, která byla okolo roku 1900 určována výhradně rámcem architektonického historismu a eklektis$\mathrm{mu}$, absorbovala $\mathrm{v}$ průběhu první poloviny 20 . století ŕadu vlivů, které vedly k její zásadní transformaci.

Jednou rovinou této transformace byl obecný vývoj architektury jako oboru, který ve formě meziválečného funkcionalismu od základu změnil svou konstituci. Tato revoluce pronikala do sakrálního prostředí spíše pozvolna, výjimku tvoří pouze stavby pro nově vzniklé církve hledající odlišnost od těch již etablovaných. Paralelně se tak projevovaly názory konzervativní a vůči nim antagonistické moderní trendy. V meziválečném období tedy lze nalézt sakrální novostavby záměrně navazující na historické tvarosloví i tradiční materialitu a současně s nimi i progresivní díla užívající strohých forem geometrické abstrakce $\mathrm{k}$ dosažení dosud nepojmenovaného prožitku čistoty a jednoduchosti. Kromě stylově čistých prŕikladů v obou těchto vývojových osách můžeme nalézt celou řadu specifických děl, jejichž tvůrci hledali určitou kompromisní formu ve velmi polarizovaném názorovém prostředí. Pro řadu z nich nešlo o skokovou změnu názoru, nýbrž o postupnou celoživotní transformaci. Jiní odmítli funkcionalismus zcela, a vědomě hledali jinou cestu.

Druhou rovinou transformace architektury byly obecný společenský vývoj stejně jako vývoj politický, které měly na život věřících podstatný vliv a vedly ke změnám liturgie, spirituálního prožívání i úlohy náboženství v rámci života moderního člověka. Tyto změny posunuly chápání sakrální architektury směrem k důrazu na její kolektivní charakter jako místa shromaždování. Můžeme samostatně zmínit zásadní vliv liturgické reformy katolické církve, která sice probíhá až od druhé poloviny 60. let, avšak její základní principy a nasměrování se formovaly již v meziválečném období.

Všechny uvedené vlivy znamenaly během několika krátkých desetiletí množství impulzů, které pro svou četnost a rozmanitost vedly k jistému druhu stylové atomizace, jejíž vliv přetrvává v české sakrální architektuře až do současnosti.

\section{ZKRÁCENÝ SOUPIS ZDROJU゚}

FILIP, Aleš. Secesní chrámy na Moravě a ve Slezsku: sakrální výtvarné umění kolem roku 1900. Vyd. 1. Brno: Barrister \& Principal, 2004. 263 s., xxxii s. barev. obr. příl. Dějiny a teorie umění; sv. 7. ISBN 80-86598-63-2. 
FILIP, Aleš, ed. a SCHMIDT, Norbert, ed. Dưm Boži a brána nebe ve 20. století: studie o sakrální architektuře: [texty z kolokvia pořádaného Mikulovským centrem pro evropskou kulturu ve spolupráci se Státním archivem Břeclav se sídlem v Mikulově, 5.-6.11.2005]. 1. vyd. Brno: Centrum pro studium demokracie a kultury, 2009. 169 s. Synésis; sv. 2. ISBN 978-807325-197-0.

GUARDINI, Romano a ZAHNER, Walter, ed. O podstatě uměleckého díla. Vyd. 1. Praha: Centrum teologie a umění, 2009. 165 s. Delfín; sv. 90. ISBN 978-80-87256-03-9.

HORSKÝ, Jiří, ed. Josip Plečnik a česká sakrální architektura první poloviny 20. století: (kostel Nejsvětějšího Srdce Páně jako součást středoevropské architektonické scény): [sborník přednášek z mezinárodní konference: 5. listopadu 2011. 1. vyd. Praha: Vysoká škola uměleckoprůmyslová v Praze, [2012]. 59 s. ISBN 978-80-86863-59-7.

MENNEKES, Friedhelm a SCHMIDT, Norbert, ed. Nadšení a pochybnost. 1, Nové umění ve starém kostele. Vyd. 1. Praha: Centrum teologie a umění, 2012. 196 s. Delfín; sv. 131. ISBN 978-80-7474-057-2.

\section{FOTOGRAFIE}

[1] Karel Hugo Kepka: kostel Nejsvětějšího Srdce Páně, Brno-Husovice, 1910. Zdroj: Brno-Husovice - Kostel Nejsvětějšího srdce Páně In: Wikimedia Commons [online] (c) Kirk 2009 [vid. 18.6.2015]. Dostupné z: https://commons.wikimedia.org/wiki/File:Brno-Husovice_-_Kostel_Nejsv\%C4\%9Bt\%C4\%9Bj\%C5\%A1\%C3\%ADho_srdce_P\%C3\%A1n\%C4\%9B.jpg

[2] Jan Víšek: Husův sbor, Brno, 1927. Zdroj: Jan Víšek - Husův sbor In: Obecní di̊m Brno [online] Obecní dům Brno (c) 2015 [vid. 18.6.2015]. Dostupné z: http://www.obecnidumbrno.cz/visek.html

[3] Josip Plečnik: kostel Nejsvětějšího Srdce Páně, Praha, 1932. Zdroj: kostel-nejsvetejsiho-srdce-pane-v-praze-187-big-image In: Kostel Nejsvětějšího Srdce Páně v Praze, ASB Portal.cz [online] Copyright (C) 2011 JAGA GROUP [vid. 18.6.2015]. Dostupné z: http://www.asb-portal.cz/fotogalerie/architektura/kostel-nejsvetejsiho-srdce-pane-v-praze-fotoalbum/ kostel-nejsvetejsiho-srdce-pane-v-praze-6 

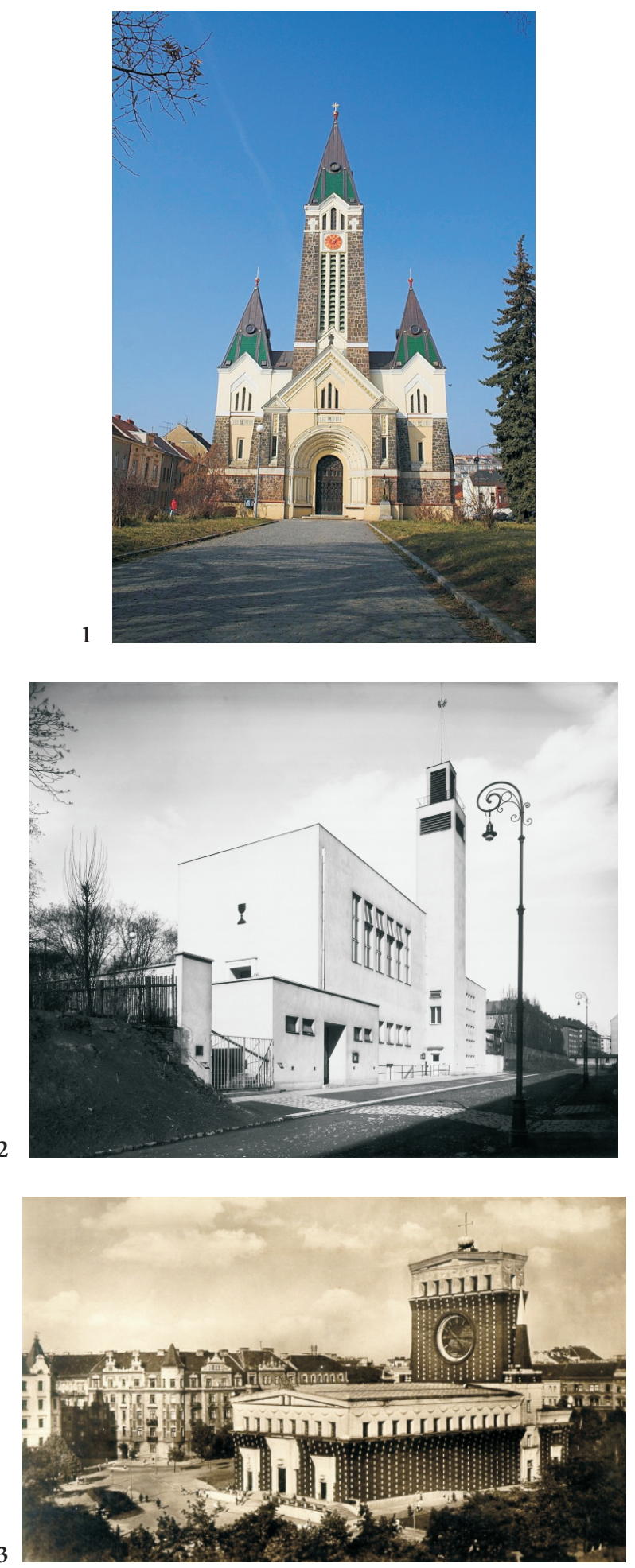